Participative Journal

Jurnal Pengabdian Pada Masyarakat

Vol. 01, No. 01, April 2021

Homepage journal: https://jurnal.jurmat.com/index.php/pj

\title{
MODEL SOSIALISASI DAN PENDAMPINGAN MAHASISWA KKP UIN MATARAM DI TENGAH PANDEMI COVID 19.
}

\author{
M. Harja Efendi*1 \\ *Affiliasi: Universitas Islam Negeri Mataram
}

\begin{abstract}
Covid-19 is a disease caused by a new type of corona virus that appeared at the end of 2019 for the first time in Wuhan, China which is currently causing a pandemic in almost all over the world. The main symptoms of Covid-19 are cough, fever and shortness of breath (Ministry of Health, 2020). Covid-19 infection also causes quite high mortality in various countries. The Covid-19 pandemic which is currently endemic to the world is currently paralyzing all sectors including the world of education, where children have to carry out distance learning activities carried out at their respective homes via the internet. This creates new problems where some areas have not been reached by internet facilities. Online learning that has not been properly prepared certainly has an impact on the learning methods used by educators. Likewise, the acceptance of learning from students is also very diverse, often they do not understand the material or delivery from the teacher. The Minister of Education and Culture, Nadiem Makarim, together with 3 other ministers, namely the Minister of Religion, the Minister of Health and the Minister of Home Affairs, made an agreement to allow face-to-face schools starting in January 2021. Higher education as an institution that has the responsibility to be able to provide knowledge to the community should carry out Community Service activities as a form of the tri dharma of higher education.
\end{abstract}

Keywords: Covid-19, e-learning, model sosialisasi

Journal Info:

Received, 10 Februari 2021 | Revised, 13 Maret 2021 | Published, 12 April 2021

${ }^{1}$ Corresponden to the author: Program Studi IPA FTK UIN Mataram, Indonesia. Email address:

harjaefendi@uinmataram.ac.id

participative journal : Jurnal Pengabdian Pada Masyarakat | h. 13 


\begin{abstract}
Abstrak
Covid-19 merupakan penyakit akibat virus corona jenis baru yang muncul pada akhir 2019 pertama kali di Wuhan, Cina yang saat ini menyebabkan pandemi hampir di seluruh dunia. Gejala utama penyakir Covid-19 yaitu batuk, demam, dan sesak napas (Kemkes, 2020). Infeksi Covid-19 juga menyebabkan kematian yang cukup tinggi di berbagai Negara. Pandemi Covid-19 yang sedang mewabah dunia saat ini melumpuhkan semua sektor termasuk dunia pendidikan, dimana anakanak harus melakukan kegiatan pembelajaran jarak jauh yang dilakukan dirumahnya masingmasing melalui internet. Hal itu membuat timbulnya masalah baru dimana beberapa daerah belum terjangkau oleh fasilitas internet. Pembelajaran daring yang belum dipersiapkan secara matang ini tentu berdampak terhadap metode pembelajaran yang dilakukan oleh tenaga pendidik. Demikian pula penerimaan atas pembelajaran dari para peserta didik pun sangat beragam, seringkali tidak memahami materi maupun penyampaian dari guru. Menteri pendidikan dan kebudayan Nadiem Makarim bersama 3 menteri lainnya yaitu Menteri Agama, Menteri Kesehatan, juga Menteri Dalam Negri membuat kesepakatan diizinkannya penerapan sekolah tatap muka mulai Januari 2021 mendatang. Perguruan Tinggi sebagai Institusi yang memiliki tanggung jawab untuk dapat memberikan ilmu kepada masyarakat sudah seharusnya melakukan kegiatan Pengabdian Kepada Masyarakat sebagai wujud tri dharma perguruan tinggi.
\end{abstract}

Kata Kunci:Covid-19, pembelajaran daring

\title{
PENDAHULUAN
}

Pengabdian Masyarakat merupakan kegiatan intrakurikuler yang memberi kesempatan kepada mahasiswa untuk belajar dan bekerja bersama-sama dengan masyarakat. Pengabdian masyarakat yang dilakukan oleh mahasiswa bukan berarti mengajar masyarakat tentang sesuatu yang terbaik untuk mereka, tetapi melakukan pemberdayaan sebagai sebuah proses pencarian (research) yang dilakukan bersama- sama untuk mencari jalan terbaik dalam penyelesaikan persoalan yang mereka hadapi. Mahasiswa melakukan tugas pendampingan terhadap apa yang dibutuhkan oleh masyarakat dalam menghadapi problem sosial yang ada di tengah-tengah mereka ( Abdullah Faizhol, (2008). Selama ini, kegiatan pengabadian masyarakat diprogramkan sebagai proses pembelajaran hidup bermasyarakat (pengabdian), karena Perguruan Tinggi dipandang sebagai menara gading dan ilmunya kurang membumi. Dalam kondisi demikian ini, orientasi program pengabdian masyarakat lebih berkisar pada : (1) pelayanan masyarakat, sehingga tidak mampu membangkitkan semangat dan menyadarkan masyarakat untuk melakukan perubahan atas problem yang mereka hadapi, (2) pelayanan untuk menyelesaikan berbagai pekerjaan di kantor pemerintah desa, (3) konsep kegiatan yang diajukan bersifat monolitis, sepihak, dan bersifat top down, karena mahasiswa menggali dan menyelesaikan 
masalah sendiri untuk masyarakat, (4) mahasiswa menempatkan diri sebagai problem solver dalam menjawab berbagai problem sosial, (5) masyarakat dijadikan sebagai objek kegiatan, (6) hanya bersifat formalitas yang cenderung ke arah seremonial akademik semata, dan (7) hasil kegiatan hanya berujud laporan kegiatan, bukan laporan riset akademik. (Suharto: 2010).

Pengabdian kepada masyarakat adalah salah satu misi dari sebuah perguruan tinggi yang pelaksanaannya perlu didukung oleh segenap warga perguruan tinggi yang disertai dengan penalaran yang utuh tentang konsep, strategi dan program. Penyelenggaraan kegiatan pengabdian masyarakat dilandasi oleh beberapa dasar pemikiran, yaitu : (Winarni, Tri. 2015).

1. Dilingkungan Perguruan Tinggi, Kuliah Kerja Nyata/Kuliah Kerja Partisipatif merupakankegiatan intrakurikuler yang pelaksanaannya mempertimbangkan keterpaduan tri aspek yaitu, pendidikan dan pengajaran, penelitian, serta pengabdian masyarakat.

2. Berdasarkan hasil analisis situasi dan kondisi pengabdian masyarakat merupakan tuntutan dalam rangka merespons kebutuhan nyata masyarakat yang sarat dengan dinamika dan permasalahan.

3. Sesuai dengan tuntutan Perguruan Tinggi maka dipandang perlu mengembangkan pengabdian masyarakat dalam bentuk dan program yang realitas, humanis, dan menyentuh langsung kebutuhan masyarakat (berbasis realitas), mendorong terciptanya kemandirian masyarakat.

Oleh sebab itu, maka yang menjadi tujuan dari kegiatan pengabdian masyarakat secara umum adalah meningkatkan kemampuan sumber daya manusia (SDM) dalam memenuhi kebutuhan masyarakat dan memecahkan problem sosial kesejahteraan sosial, pencerahan, dan pembebasan sesuai dengan visi, misi dan fungsi Perguruan Tinggi.( Abdullah Faizhol, (2008).

Pengabdian masyarakat/KKP yang dilakukan mahasiswa UIN Mataram di masa pandemi Covid-19 ini mengacu pada buku pedoman KKP-DR "Penanggulangan Covid-19 Berbasis Moderasi Agama", Kuliah Kerja Partisipatif (KKP) merupakan salah satu mata kuliah yang wajib diikuti oleh seluruh mahasiswa UIN Mataram melalui bimbingan Dosen Pembimbing Lapangan (DPL) serta berlokasi dibeberapa wilayah yang menjadi sasaran pelaksanaan KKP. Pada dasarnya KKP merupakan mata kuliah dilapangan yang bertujuan untuk membekali mahasiswa dalam mengaplikasikan keilmuan yang telah dipelajari selama perkuliahan. Diantara tujuan tersebut adalah pada kegiatan memecahkan berbagai fenomena yang terjadi didalam masyarakat melalui pengembangan potensi yang ada didalam masyarakat itu sendiri. (P2M LPM UIN Mataram) 
Memasuki awal tahun 2020, Indonesia secara khusus dan dunia mengalami pandemic global yaitu munculnya virus Covid-19 yang mengakibatkan persoalan serius pada berbagai belahan dunia termasuk Indonesia sendiri. Berbagai kebijakan telah dilakukan pemerintah dalam menanggulangi pandemic yang dihadapi.Salah satunya adalah dengan melibatkan berbagai pihak untuk membantu penanganan dan pencegahan salah satunya adalah keterlibatan dan keikutsertaan universitas. Universitas melalui kebijakan akademis dituntut dapat berperan aktif dalam membantu msayarakat dan pemerintah serta menjadi solution maker terhadap permasalahan yang sedang dihadapi. (P2M LPM UIN Mataram)

Salah satu strategi yang dilakukan oleh universitas dalam membantu percepatan penanganan dan pencegahan adalah melalui keterlibatan mahasiswa yang langsung dapat bersentuhan dengan masyarakat melalui program Kulih Kerja Partisipatif (KKP). Meskipun pelaksanaan KKP yang bersentuhan secara langsung dengan masyarakat terganggu dengan adanya virus Covid-19, tidak menyurutkan keikutsertaan universutas dalam menangani pandemic yang dihadapi. Berbagai program, strategi dan kebijakan pun telah diambil untuk mensiasati keterlibatan universitas dan mahasiswa dalam membantu penanganan dan pencegahan virus Covid-19 melalui program Kuliah Kerja Partisipatif Dari Rumah (KKP-DR).

Pelaksanaan KKP-DR dapat dilakukan oleh mahasiswa melalui berbagai program pilihan sesuai dengan keadan dan kebutuhan di lokasi KKP dengan pemanfaatan IPTEK secara online. Diantara program-program pilihan tersebut adalah edukasi masyarakat, relawan pencegahan Covid-19 secara langsung dilingkungan masyarakat dan puskesmas serta posko penanganan terdekat dengan tempat tinggal, kampanye kesehatan dan pencegahan melalui platform media sosial seperti instagram, facebook, twitter, whatsapp, youtube serta platform-platform popular lainnya dalam bentuk video, foto, poster, serta karya tulis dalam bentuk buku.

Secara yuridis formal penyelenggaraan Kuliah Kerja Partisipatif (KKP) memiliki landasan; Keputusan Rektor UIN Mataram Nomor; 1006 Tahun 2020 tentang Tim Pelaksana Kuliah Kerja Partisipatif Dari Rumah (KKP) UIN Mataram Tahun 2020.

Berdasarkan latar belakang dan identifikasi masalah diatas maka rumusan penelitian yang akan diteliti adalah sebagai berikut; Bagaimanakah Model Sosialisasi dan Pendampingan Mahasiswa KKP UIN Mataram Di Masa Pandemi Covid-19

\section{METODE}

Metode penelitian yang digunakan adalah metode survey yang berupaya untuk mengemukakan model pendampingan mahsiswa kkp uin mataram dalam melaksanakan 
program kerja yang telah ditetapkan dengan mengikuti format protokol pencegahan covid-19. (Nasution: 2004)

Pengumpulan data dilakukan dengan menggunakan observasi kepada mahasiswa yang melaksanakan KKP. Seting kegiatan dan lokasi KKP sesuai dengan peraturan LP2M UIN Mataram, dilaksanakan sebagai berikut; (untuk semua jurusan)

a. KKP-DR dapat diwujudkan dengan cara melakukan penguatan atas kesadaran dan kepedulian terhadap wabah Covid-19

b. Edukasi literasi covid-19

c. Sosialisasi dan penyuluhan pencegahan dan penanganan Covid-19 didaerah masing-masing melalui peran media sosial

d. Membagikan Alat Perlindungan Diri (APD) standar berupa masker dan handsanitizerkepada masyarakat setempat. Anggaran disesuaikan dengan kemampuan dan pengaturan dari peserta KKP-DR UIN Mataram.

Lokasi KKP DR UIN Mataram berdasarkan pembagian kelompok dapat dilihat dibawah ini

1. Desa Aik Bukak

2. Desa Aik Darek

3. Desa Lunyuk Rea

4. Desa Gerunung

5. Desa Giri Sasak

\section{HASIL DAN PEMBAHASAN}

\section{Desa Aik Bukak}

Desa Aik Bukak, Kec. batukliang utara, Kab. Lombok Tengah, Prov. NTB. Secara Geografis desa Aik Bukak terletak pada $8^{\circ} 34^{\prime} 34.8^{\prime \prime S} 116^{\circ} 20^{\prime} 43.8^{\prime \prime E}$. apabila di tempuh dari kota mataram membutuhkan waktu 49 menit. Aik bukak merupakan desa yang berada di kabupaten Lombok tengah dengan taman wisata yang terkenal yaitu taman wisata aik bukak. Desa aik bukak merupakan desa yang berada di sebelah utara kabupaten Lombok tengah. Sedangkan apabila ditempuh dari pusat kabupaten Lombok tengah hanya membutuhkan waktu 36 menit.

Sebagian besar desa aik bukak dikelilingi oleh hutan dan sawah. Sekitar 30\% terdiri dari hutan dengan pohon-pohon besar seperti beringin, ketapang, mahoni, dan lain-lain. Sedangkan 20\% nya adalah persawahan dan sisanya ditinggali oleh penduduk. Desa Aik Bukak berbatasan dengan 
desa Setiling di sebelah timur, desa teratak di sebelah barat, desak Aik berik di sebelah utara, dan desa Mas-mas di sebelah selatan.

\section{Pendampingan yang dilakukan}

Berdasarkan data dari ketua pemberdayaan masyarakat, tidak satupun warga desa aik bukak mengalami stunting sedangkan pernikahan usia dini berjumlah 18 orang. 10 orang berasal dari grade SMA, 3 SMP, dan 3MTs. Pernikahan usia dini di aik bukak ini di sebabkan oleh kurangnya sosialisasi tentang bahayanya pernikahan usia dini oleh desa maupun pejabat pemerintah atau instansi terkait misalnya sekolah. Keadaan ekonomi warga juga menjadi pemicu pernikahan usia dini.

Untuk kesehatan masyarakat sendiri berdasarkan profil desa aik bukak 2020 untuk kualitas ibu hamil dengan jumlah ibu hamil diperiksa di posyandu sebanyak 108 orang, ibu hamil diperiksa di puskesmas sebanyak 108 orang, jumlah ibu melahirkan 155 orang, dan jumlah ibu nifas hidup sebanyak 155 orang. Untuk kualitas bayi dengan jumlah keguguran kandungan sebanyak 9 Orang, jummlah bayi lahir kurang dari 2,5 kg sebanyak 2 Orang. Untuk pertolongan persalinan dengan jumlah tindakan sebanyak 155 dari dokter, bidan dan perawat.

\section{Desa Aik Darek}

Desa Aik Dareq merupakan Desa yang terbagi menjadi 13 Dusun, di antaranya yaitu Dusun Aik Dareq, Kembang Kerang 1, Kembang Kerang 2, Kembang Kerang 3, Kembang Kerang 4, Pancordao 1, Pancordao 2, Pancordao 3, Sengkol 1, Sengkol 2, Cempaka, Dasan Makmur, dan Dasan Cermen, yang dimana dalam masing-masing Dusun telah memiliki kepala Dusun. Selain itu dalam setiap arah wilayahnya Desa Aik Dareq dibatasi oleh beberapa Desa dimana pada bagian utara dibatasi oleh Desa Lantan, pada bagian selatan dibatasi oleh Desa Mekar Bersatu, bagian timur dibatasi oleh Desa Selebung dan Mantang, dan bagian barat dibatasi oleh Desa Sepakek. Luas Desa Aik Dareq 595.100

\section{Pendampingan yang dilakukan}

Berikut jumlah pendataan stanting dan kelompok kesehatan yang ada di Desa Aik Dareq

Tabel 1. Data Posyandu desa Aik darek

\begin{tabular}{|l|l|}
\hline \multicolumn{1}{|c|}{ Jumlah Posyandu } & 9 buah yang tersebar di seluruh Dusun \\
\hline Jumlah kader posyandu & 25 orang \\
\hline Jumlah apotik & 1 unit \\
\hline
\end{tabular}

participative journal : Jurnal Pengabdian Pada Masyarakat | h. 18 
participative journal : Jurnal Pengabdian Pada Masyarakat

\begin{tabular}{|l|l|}
\hline BPM yayasan atau swasta & 1 unit \\
\hline Bidan Desa & 8 orang \\
\hline Kantor praktek dokter & 2 unit \\
\hline Dokter umum & 1 orang \\
\hline Dokter gigi & 2 orang \\
\hline
\end{tabular}

Sumber:Profil Desa Aik Dareq 2019

\section{Pendataaan pernikahan usia dini}

Pernikahan dini adalah pernikahan anak-anak yang belum cukup umur sesuai dengan peraturan perundang undangan Republik Indonesia. Jumlah pernikahan usia dini sangatlah minim karna hanya satu kali terjadi selama 4 tahun terakhir.

\section{Desa Lunyuk Rea}

Desa Lunyuk Rea, Kecamatan Lunyuk, KabupatenSumbawa, Provinsi Nusa Tenggara Barat (NTB). DesaLunyuk Rea merupakansalahsatudesa yang letaknya berbatasan dengan Desa Ledang (Kecamatan Lenang Guar) di sebelah Utara, Desa Lunyuk Ode (Kecamatan Lunyuk) di sebelah Selatan, Desa Leben (Kecamatan Ropang) di sebelah Timur, dan Desa Jamu (Kecamatan Lunyuk) di sebelah Barat. DesaLunyuk Rea memiliki luas pemukiran sebesar 79 ha/m2, luas persawahan $618 \mathrm{ha} / \mathrm{ma}$, luas perkebunan $727 \mathrm{ha} / \mathrm{m} 2$, luas kuburan $8 \mathrm{ha} / \mathrm{m} 2$, luas pekarangan $94 \mathrm{ha} / \mathrm{m} 2$, luas taman 0,20 ha/m2, luas perkantoran $1 \mathrm{ha} / \mathrm{m} 2$, dan luas prasarana umum lainnya sebesar $7 \mathrm{ha} / \mathrm{m} 2$. Jadi jumlah luas totalnya sebesar $1529,20 \mathrm{ha} / \mathrm{m} 2$.

Rata-rata pekerjaan masyarakat di DesaLunyuk Rea yaitu sebagai petani,dengan jumlah total keluarga petani dengan kepemilikan lahan tanam pangan sebanyak 834 keluarga. Tanaman pangan yang dimaksud berupa tanaman jagung dengan luas komoditas $932 \mathrm{Ha}$ dan hasil panen sebanyak 16.524 Ton/ha. Kemudian ada tanaman kedelai dengan luas komoditasnya 7 Ha dan hasil panen sebanyak 4 Ton/ha. Tanaman padi sawah seluas $1236 \mathrm{Ha}$ dengan hasil panen sebanyak 9.888 Ton/ha. Padi lading seluas 8 Ha dengan hasil panen sebanyak 16 Ton/ha. Tanaman cabe seluas $12 \mathrm{Ha}$ dengan hasil panen sebanyak 25 Ton/ha. Kemudian ada tanaman sawi dengan luas 0,25 Ha dengan hasil panen sebanyak 0,25 Ton/ha. 


\section{Pendampingan yang dilakukan}

Desa Lunyuk rea. Data jumlah POSYANDU sebanyak 7 dan pusekesmas pembantu sebanyak 1 unit. Jenis POSYANDU Keluarga ini terdiri dari :
a. POSYANDU Balita
b. POSYANDU Remaja
c. POSYANDU Lansia

\section{Pendataan pernikahan usia dini}

Kasus pernikahan usia dini di Desa Lunyuk Rea dapat berdasarkan data yang telah didapatkan yaitu dalam 1 tahun pernikahan usia dini terjadi sebanyak 10-20 pasangan.

1. Kesejahteraan Keluarga :

a. Jumlah keluarga prasejahtera 156 Keluarga

b. Jumlah keluarga sejahtera 1 sebanyak 291 Keluarga

c. Jumlah keluarga sejahtera 2 sebanyak 304 Keluarga

d. Jumlah keluarga sejahtera 3 sebanyak 108 Keluarga

e. Jumlah keluarga sejahtera 3 plus sebanyak 9 Keluarga

Total jumlah kepala keluarga sebanyak 868 Keluarga

\section{Desa Gerunung}

Kelurahan Gerunung kecamatan Praya kabupaten Lombok Tengah, kelurahan ini memiliki 6 lingkungan yaitu, lingkungan Taggak, lingkungan Bayan, lingkungan Gerunung, lingkungan Lendang jangkrik, lingkungan kesambik numpuk dan lingkungan Polak penyayang. Kelurahan gerunung sendiri memiliki luas 312 hektar serta memiliki 6.500

Pendataan Pernikahan Usia Dini Kelurahan Gerunung lebih khususnya Lingkungan Tanggak ada beberapa orang yang melakukan pernikahan yang tidak sesuai dengan undang-undang Hukum pernikahan Kompilasi Hukum Islam(HKI) dan Syarat-syarat perkawinan termuat dalam pasal 7 UU RI No 16 Tahun 2019 yang berbunyi "Perkawinan hanya di izinkan apabila pria dan wanita sudah mencapai umur 19 (sembilan belas) tahun". Dan yang sudah di perbaharui tentang batas Usia. atau yang melakukan pernikahan di usia dini nya kurang lebih lima orang, dan kami melakukan surpe kemudian sembari kami sosialisasi tentang undang-undang hukum pernikahan yang terbaru. Masyarakat lingkungan Tanggak lebih mementingkan atau mendahuluikan pendidikan ketimbang di bandingkan dengan pernikahan di usia dini, dan masyarakat sangatlah antusias di dalam pendidikannya sampai jenjang sarjana. 


\section{Desa Leneng}

Kelurahan Leneng yang termasuk kedalam salah satu wilayah Kecamatan Praya, Kabupaten Lombok Tengah. Jarak desa Leneng dengan ibukota kecamatan di kecamatan praya yaitu $5 \mathrm{~km}$ dengan jarak tempuh 11 menit menggunakan kendaraan, Hal ini menunjukkan bahwa leneng merupakan salah satu desa yang dekat dengan kota dan bisa dikatakan leneng sebagai pintu gerbang kota, karena disebelah barat Leneng terdapat Kantor Bupati Lombok tengah, Poltekpar, IPDN. Adapun yang dimaksud sebagai posisi kegiatan KKP-DR di kelurahan leneng berpusat di lingkungan wakan, Embung Bengkel dan Juring.

\section{Pendampingan yang dilakukan}

Stunting adalah kondisi gagal pertumbuhan pada anak (pertumbuhan tubuh dan otak) akibat kekurangan gizi dalam waktu yang lama. Sehingga, anak lebih pendek atau perawakan pendek dari anak normal seusianya dan memiliki keterlambatan dalam berpikir. Kejadian stunting secara tidak langsung dipengaruhi oleh faktor sosial, ekonomi, seperti tingkat pendidikan, pendapatan keluarga, dan ketersediaan pangan untuk memenuhi kebutuhan pangan yang cukup baik segi kuantitas dan kualitas dan keamanannya. Status ekonomi keluarga dipengaruhi oleh beberapa faktor, antara lain pekerjaan orang tua, tingkat pendidikan orang tua dan jumlah anggota keluarga. Anak pada keluarga dengan tingkat ekonomi rendah lebih berisiko mengalami stunting karena kemampuan pemenuhan gizi yang rendah, meningkatkan risiko terjadinya malnutrisi.

Tabel 2. Data Stunting di Kelurahan Leneng

\begin{tabular}{|c|c|c|c|c|c|c|c|c|c|}
\hline \multirow{3}{*}{ NO } & \multirow{3}{*}{ POSYANDU } & \multicolumn{8}{|c|}{ TINGGI BADAN/UMUR } \\
\hline & & \multicolumn{2}{|c|}{ SANGAT PENDEK } & \multicolumn{2}{|c|}{ PENDEK } & \multicolumn{2}{|c|}{ NORMAL } & \multicolumn{2}{|c|}{ TINGGI } \\
\hline & & $0-23$ Bln & 0-59 Bln & $\begin{array}{l}0-23 \\
\text { Bln }\end{array}$ & $\begin{array}{l}0-59 \\
\text { Bln }\end{array}$ & $\begin{array}{l}0-23 \\
B \ln \end{array}$ & $\begin{array}{l}0-59 \\
B \ln \end{array}$ & $\begin{array}{l}0-23 \\
\text { Bln }\end{array}$ & $\begin{array}{l}0-59 \\
\text { Bln }\end{array}$ \\
\hline 1 & $\begin{array}{l}\text { Embung } \\
\text { Bengkel }\end{array}$ & 0 & 0 & 1 & 2 & 21 & 43 & 0 & 0 \\
\hline 2 & Handayani & 0 & 3 & 5 & 11 & 48 & 99 & 0 & 1 \\
\hline 3 & Juring & 2 & 1 & 1 & 6 & 51 & 97 & 0 & 0 \\
\hline 4 & Leneng & 0 & 1 & 1 & 5 & 51 & 140 & 0 & 1 \\
\hline 5 & Tebero & 0 & 1 & 1 & 7 & 24 & 59 & 1 & 1 \\
\hline 6 & Wakan & 0 & 1 & 3 & 4 & 35 & 78 & 0 & 0 \\
\hline \multicolumn{2}{|c|}{ Jumlah } & 2 & 7 & 12 & 35 & 230 & 616 & 1 & 3 \\
\hline
\end{tabular}

Sumber: Puskesmas Praya 


\section{Pendataan pernikahan dini}

Pernikahan dini merupakan salah satu problem dalam masyarakat yang disebabkan oleh berbagai faktor yang mendorong anak untuk melakukan pernikahan di usia dini. Dikatan pernikahan dini ketika usia mereka masih dibawah 19 tahun. Berdasarkan hasil pendataan di lapangan, pernikahan dini di kelurahan leneng masih sangat minim, hanya beberapa anak saja pada suatu lingkungan yang melakukan pernikahan dini pada usia SMP maupun SMA seperti pada lingkungan embung bengkel terdapat 3 anak yang melakukan pernikahan dini dalam kurun waktu

5 tahun terakhir. Terdapat beberapa faktor penyebab terjadinya pernikahan usia dini masih sering terjadi diantaranya:

a. Pengaruh lingkungan tempat tinggal menyebabkan pergaulan tidak terkontrol di kalangan remaja/anak-anak.

b. Orang tua yang tidak mampu menafkahi anak-anaknya dengan tujuan ingin mengurangi beban menafkahi.

c. Putus sekolah

d. Kurangnya kesadaran akan pentingnya pendidikan.

\section{Kesimpulan}

KKP-DR 2020 merupakan KKP yang berbeda dari tahun-tahun sebelumnya. KKP-DR dilaksanakan dari rumah masing-masing. KKP-DR ini dilaksanakan dari bulan juli sampai agustus 2020. Hal ini dilakukan untuk mencegah penyebaran virus corona. Tema KKP-DR yang sekarang adalah pendampingan dan sosialisasi pencegahan covid-19. Pelaksanakan KKP-DR pencegahan virus corona merupakan program utama dari kelompok 10 yaitu sosialisasi pencegahan covid-19, pembagian masker, pembuatan hand sahanitizer, dan pembuatan disenfektan. Selain itu program KKP yang lain adalah program kampung sehat yang terdiri dari penghijauan, pemasangan pamflet, pembersihan jalan di trotoar desa, pembibitan dan pembenihan tanaman sayur, dan sosialisai door to door untuk pencegahan covid-19. Pembagian vitamin kepada lansia untuk meningkatkan system imun juga telah terlaksana. Hal ini dilakukan karena system imun lansiaa yang sudah menurun dan mudah terpapar virus corona. Pembuatan pupuk cair berbahan dasar arganik yang telah kami bagikan kepada masyarakat. Karena dalam kelompok 10 terrdiri dari berbagai jurusan kami saling membantu dalam program utama jurusan seperti promosi UMKM, pengembangan wisata desa, dan perternakan. 
participative journal : Jurnal Pengabdian Pada Masyarakat

\section{Ucapan Terima Kasih}

Ucapan terimakasih yang mendalam kepada LP2M UIN Mataram yang sudah mendukung terselenggaranya kegiatan pengabdian pada masyarakat ini melalui program KKP mahasiswa.

\section{Daftar Pustaka}

Faizhol, Abdullah, 2008. Metode dan Teknik Kuliah Kerja Nyata Transformatif. Nasution, 2004. Metode Penelitian. Yogyakarta : Fakultas Psikologi UGM P2M LPM UIN Mataram, 2020. Buku Pedoman KKP DR, UIN Mataram Suharto, Edi. 2010. Membangun Masyarakat Memberdayakan Rakyat "Kajian Strategi Pembangunan Kesejahteraan Sosial dan Pekerjaan Sosial". Bandung : PT. Refika Aditama. Winarni, Tri. 2015. Memahami Pemberdayaan Masyarakat Desa Partisipatif dalam Orientasi Pembangunan Masyarakat Desa Menyongsong Abad 21: Menuju Pemberdayaan Pelayanan Masyarakat. Yogyakarta : Adita Media. 